\title{
Seedling growth of Schizolobium parahyba on different substrates and irrigation levels
}

Crescimento de mudas de Schizolobium em diferentes sustratos e níveis de irrigação

\author{
Débora Zumkeller Sabonaroํ \& João Antonio Galbiatti²
}

\begin{abstract}
The present study aimed to assess the behavior of seedlings of Schizolobium parahyba (Vell.) Blake growing on different substrates and irrigation levels, and to study the use of urban waste compost in substrates. The experiment was carried out in the College of Agricultural Sciences, Universidade Estadual Paulista (UNESP), Department of Agricultural Engineering, Jaboticabal Campus, state of São Paulo, Brazil. The experimental design used was completely randomized, consisting of 30 treatments in a factorial design with 15 substrates and two irrigation levels in four replicates. The substrates were composed of different materials: urban waste, Plantmax ${ }^{\circledR}$, dry cattle manure, vermiculite and soil. For the study of seedling growth, the following characteristics were evaluated: height $(H)$, root-collar diameter (D), number of leaves, shoot dry weight, root dry weight, total dry weight, H/D ratio, Dickson's quality index, and the ratio between height and shoot dry weight (H/SDW). Assessments of the first three characteristics were carried out 20,35, 50 and 65 days after sowing. Results showed that urban waste compost increased the growth of Schizolobium parahyba. There were significant differences for the irrigation levels tested; with better results for $150 \%$ ET compared to $100 \%$ ET irrigation level.
\end{abstract}

Key words: urban waste compost, soil fertility, native species.

\section{Resumo}

Este trabalho teve como objetivo avaliar o comportamento de mudas de guapuruvu (Schizolobium parahyba (Vell.) Blake) crescidas em substratos constituídos por misturas de cinco materiais, em diferentes combinações, bem como analisar a influência da irrigação no crescimento das mudas em viveiro. $\mathrm{O}$ experimento foi instalado no Departamento de Engenharia Rural da Faculdade de Ciências Agrárias e Veterinárias - UNESP, Campus de Jaboticabal - SP, Brasil. O delineamento utilizado foi o inteiramente casualizado consistindo de 30 tratamentos num esquema fatorial $15 \times 2$ (15 substratos e 2 níveis de irrigação), em 4 repetições. Os substratos foram compostos por combinações de diferentes materiais: Composto de lixo urbano, Plantmax ${ }^{\circledR}$, esterco bovino curtido, vermiculita e solo. Para o estudo do crescimento das mudas, as seguintes características foram avaliadas: altura da parte aérea (H), o diâmetro do colo (D), o número de folhas, o peso da massa seca da parte aérea, do sistema radicular, e peso total, a relação H/D, o Índice de Qualidade de Dickson e a relação altura da parte aérea/ peso da massa seca da parte aérea. As três primeiras características foram medidas aos 20,35, 50 e 65 dias após a semeadura. A análise dos resultados obtidos permitiu concluir que o composto de lixo urbano favoreceu o crescimento das mudas de Schizolobium parahyba. Quanto aos níveis de irrigação testados, pôde-se verificar que houve diferenças estatísticas e o nível de irrigação 150\% ET se destacou em relação ao 100\% ET.

Palavras-chave: composto de lixo urbano, fertilidade do solo, espécies nativas.

\section{Introduction}

One of the greatest concerns of mankind is the increase in urban waste production. Waste can cause serious environmental problems if disposal is done without safe criteria. The most adequate waste management form is by home composting, a process that generates waste compost. The inclusion of waste compost as a nutrient source in compound substrates for the production of tree seedlings may be an alternative to decrease production costs, and

\footnotetext{
'Universidade Estadual Paulista, Instituto de Biociências, Campus de Rio Claro, Av. 24 A 1515, 13506-900, Rio Claro, SP, Brazil.

${ }^{2}$ Universidade Estadual Paulista,Faculdade de Ciências Agrárias e Veterinárias, Depto. Agricultural Engineering, Via de Acesso Prof. Paulo Donato Castellane s/n, 14884-900, Jaboticabal, SP, Brazil.

${ }^{3}$ Author for correspondence: dzsabonaro@hotmail.com
} 
even to allow using this product in activities other than agriculture, that might generate new markets for this organic fertilizer (Nóbrega et al. 2008).

Among the main positive effects of waste compost application is the variation of chemical attributes in acid soils, such as increase in $\mathrm{pH}$, neutralization of exchangeable acidity, reduction in potential acidity, increase in organic carbon content and in the availability of phosphorus, potassium, calcium, magnesium and increase in cationic exchange capacity (Kiehl 1985; Xin et al. 1992; Wong et al. 1998; Abreu Junior et al. 2000; Oliveira 2002), which may represent improvement in the chemical, physical and biological properties of the substrate used that may positively affect seedling production.

Seedling quality can be affected by substrate composition. Therefore, it is very important that, during cultivation, water and nutrients are provided in adequate quantities and that the physical properties of the substrate are not limiting. For substrates with lower water retention capacity (rice hull ash, sand, crushed coal, etc.), for example, irrigation must be more frequent or at higher volume than for substrates with higher water retention capacity (subsoil earth, organic compost, humus, coconut fiber, etc.) (Wendling \& Gatto 2002).

Moreover, quality assessment of seedlings in condition for planting takes into account morphological and physiological aspects. Physiological parameters are difficult to measure and analyze, mainly in commercial forest nurseries. Frequently, they do not allow assessing efficiently the real survival capacity and initial growth of seedlings after planting, that does not meet the expectations of any forestry enterprise (Gomes 2001).

Although the ratio between shoot dry weight and root dry weight is considered to be an efficient and safe index to assess seedling quality, it may not properly express growth in the field (Burnett 1979), and should be complemented with other parameters such as shoot height and rootcollar diameter.

According to Carneiro (1995), the shoot height of the seedlings at the final transplant plays an important role in their survival during the first years after planting. This author emphasizes, though, that seedlings with higher survival perspective and higher initial growth must exhibit a root-collar diameter equal to or greater than the ratio [height $(\mathrm{cm}) / 8.1]$.
Schizolobium parahyba (Vell.) Blake, popularly known as Brazilian firetree or guapuruvu, is native to the Atlantic Forest, and occurs from the state of Bahia to Santa Catarina. The Brazilian firetree is a pioneer species and one of the fastest-growing native species; it can be used in the reforestation of degraded areas in mixed compositions (Lorenzi 1992).

The aim of this study was to assess seedling growth of Schizolobium parahyba (Vell.) Blake cultivated in substrates composed of different combinations of five materials, including urban waste compost; as well as to analyze the effect of irrigation on the growth of these seedlings under nursery conditions.

\section{Material and Methods}

The experiment was carried out in a greenhouse, in an area belonging to the Department of Agricultural Engineering, Faculdade de Ciências Agrárias e Veterinárias Universidade Estadual Paulista (UNESP), Jaboticabal Campus, state of São Paulo, southeastern Brazil, $\left(21^{\circ} 15^{\prime} 15^{\prime \prime} \mathrm{S}, 48^{\circ} 18^{\prime} 09^{\prime \prime} \mathrm{W}\right.$; $595 \mathrm{~m}$ ). According to Köppen, the regional climate is classified as $\mathrm{Cwa}$, i.e. humid subtropical with dry winter. Average annual rainfall is c. $1,400 \mathrm{~mm}$ and average annual temperature is c. $21^{\circ} \mathrm{C}$.

Seeds of Schizolobium parahyba (Vell.) Blake for seedling production were obtained at the Experimental Nursery of Ornamental and Forest Seedlings ("Viveiro Experimental de Mudas Ornamentais e Florestais") of Faculdade de Ciências Agrárias e Veterinárias.

It was necessary to perform a pre-germination treatment in boiling water for two minutes (Ledo 1977) in order to break seed dormancy.

Hard plastic tubes were used (height $13 \mathrm{~cm}$, with capacity for $160 \mathrm{~cm}^{3}$ of substrate), which were filled with different substrates and placed in a support structure, under a $30 \%$ shading polypropylene screen. Two seeds were placed in each tube; thinning was done around 30 days after germination. Seven days after thinning, seedlings were placed in full sunlight.

Initial and topdressing mineral fertilization followed Gonçalves et al. (1997).

Fifteen substrates were tested, resulting from the combination of the commercial substrate Plantmax ${ }^{\circledR}$, widely used in the production of native seedlings, with cattle manure, waste compost, 
vermiculite and soil. The treatments, in volume or weight percentage of each component, are described in Table 1. The organic waste for the compost was obtained in São José do Rio Preto (state of São Paulo), a city that carries out separate collection and composting of organic waste. Vermiculite of medium texture was used. We used soil samples of dystrophic red latosol with medium texture from a mesophilic semi-deciduous residual forest, removed from the 0-20 cm layer. Chemical and granulometric analyses (Tab. 2) were carried out at the Department of Soils and Fertilizers of Faculdade de Ciências Agrárias e Veterinárias, following the protocol recommended by Tomé Júnior (1997).

Additionally, in order to define the water blades to be applied in irrigation, evapotranspiration (ET) was estimated with an atmometer (Broner \& Law 1991). Based on these measures two irrigation levels were defined: A- (100\%) and B - (150\%) of evapotranspiration (ET), applied manually every day.

We used an experimental design with randomized blocks, with 30 treatments in a $15 \times 2$ factorial design (15 substrates and 2 irrigation levels) with four replicates.

Seedlings were cultivated in hard plastic tubes $\left(13 \mathrm{~cm}\right.$ height, with capacity for $160 \mathrm{~cm}^{3}$ of substrate), which were filled with different substrates and placed in a support structure, under a $30 \%$ shading polypropylene screen.

Cultivation in tubes demands frequent irrigation and fertilization and, therefore, it is necessary to know the physico-chemical properties of the substrates, since they are important factors for management and quality control of the cultures. So, we analyzed the characteristics of the 15 treatments used in the present study: $\mathrm{pH}$ obtained with a potentiometer and deionized water; apparent density, following the protocol proposed by Gonçalves \& Poggiani (1996); and chemical composition (Tab. 3).

Seedling growth characteristics of Schizolobium parahyba were: shoot height (H $\mathrm{cm}$ - measured from the substrate to the highest
Table 1 - Volumetric composition of substrates used to produce seedlings of Schyzolobium parahyba.

\begin{tabular}{cccccc}
\hline \multicolumn{7}{c}{ Substrates } & Plantmax & $\begin{array}{c}\text { Manure } \\
\text { compost }\end{array}$ & \multicolumn{2}{l}{$\begin{array}{l}\text { Urban } \\
\text { waste }\end{array}$} \\
\hline 1 & 75 & - & - & 15 & 10 \\
2 & 60 & 15 & - & 15 & 10 \\
3 & 45 & 30 & - & 15 & 10 \\
4 & 30 & 45 & - & 15 & 10 \\
5 & 15 & 60 & - & 15 & 10 \\
6 & - & 75 & - & 15 & 10 \\
7 & 60 & - & 15 & 15 & 10 \\
8 & 45 & - & 30 & 15 & 10 \\
9 & 30 & - & 45 & 15 & 10 \\
10 & 15 & - & 60 & 15 & 10 \\
11 & - & - & 75 & 15 & 10 \\
12 & - & 60 & 15 & 15 & 10 \\
13 & - & 45 & 30 & 15 & 10 \\
14 & - & 30 & 45 & 15 & 10 \\
15 & - & 15 & 60 & 15 & 10 \\
\hline
\end{tabular}

leaf), stem diameter at $3 \mathrm{~cm}$ from the substrate (D $\mathrm{mm}$ ), number of leaves (NF), shoot dry weight (SDW - g plant $^{-1}$ ) and root dry weight (RDW- plant $\left.^{-1}\right)$.

The assessment of $\mathrm{H}, \mathrm{D}$ and NL were carried out $20,35,50$ and 65 days after sowing (d.a.s). We monitored seedlings until they showed adequate conditions to be planted in the field.

At the end of the experiment, in order to measure SDW and RDW, the plants were separated into root and shoots, washed in distilled water and dried in a forced air circulation oven at $65^{\circ} \mathrm{C}$ to constant weight. With the sum of these data, we obtained the total dry weight (TDW), the ratio between height and shoot dry weight $(\mathrm{H} /$ SDW), the ratio between shoot dry weight and root dry weight (SDW/RDW), and Dickson's quality index (DQI) (Dickson et al. 1960), with the formula: $\mathrm{DQI}=\mathrm{TDW} /[(\mathrm{H} / \mathrm{RCD})+(\mathrm{SDW} / \mathrm{RDW})]$, where RCD stands for root-collar diameter.

An analysis of variance with $\mathrm{F}$ test was calculated, with $1 \%$ and $5 \%$ significance levels; averages were compared with Scott Knott's test with $1 \%$ to $5 \%$ significance level.

Table 2 - Chemical and granulometric analysis of the soil used to produce seedlings of Schyzolobium parahyba.

\begin{tabular}{|c|c|c|c|c|c|c|c|c|c|c|c|c|c|c|}
\hline$\overline{\mathrm{pH}}$ & $\begin{array}{c}\text { Organic } \\
\text { matter }\end{array}$ & $\mathrm{P}$ & $\mathrm{K}$ & $\mathrm{Ca}$ & $\mathrm{Mg}$ & $\mathrm{H}+\mathrm{Al}$ & SB & $\mathrm{T}$ & V & clay & silt & $\begin{array}{l}\text { Fine } \\
\text { sand }\end{array}$ & $\begin{array}{c}\text { Coarse } \\
\text { sand }\end{array}$ & $\begin{array}{c}\text { Texture } \\
\text { class }\end{array}$ \\
\hline $\mathrm{CaCl}_{2}$ & $\mathrm{gdm}^{-3}$ & $\begin{array}{l}\text { resi } \\
\mathrm{Mg}\end{array}$ & $\ldots$ & & $\mathrm{mol}_{\mathrm{c}}$ & $m^{-3}$ & & $\%$ & & & $-\mathrm{g}$ & 1 & & \\
\hline 4.2 & 21 & 2 & 0.6 & 5 & 3 & 42 & 8.6 & 50.6 & 17 & 320 & 40 & 270 & 370 & medium \\
\hline
\end{tabular}


Table 3 - Physico-chemical characteristics of the fifteen substrates tested. NH stands for natural humidity and DB stands for dry basis (constant mass dried at $110^{\circ} \mathrm{C}$ ).

\begin{tabular}{|c|c|c|c|c|c|c|c|c|c|c|c|}
\hline Substrates & Definition & $\begin{array}{l}\mathrm{pH} \text { in } \\
\mathrm{CaCl}_{2} \\
0.01 \mathrm{M}\end{array}$ & $\begin{array}{l}\text { Density } \\
\left(\mathrm{g} / \mathrm{cm}^{3}\right)\end{array}$ & $\begin{array}{l}\text { Total } \\
\text { Nitrogen } \\
(\%)\end{array}$ & $\begin{array}{l}\text { Phosphorous } \\
\left(\mathrm{P}_{2} \mathrm{O}_{5}\right)(\%)\end{array}$ & $\begin{array}{l}\text { Potassium } \\
\mathrm{K}_{2} \mathrm{O}(\%)\end{array}$ & $\begin{array}{l}\text { Calcium } \\
(\mathrm{Ca})(\%)\end{array}$ & $\begin{array}{l}\text { Total } \\
\text { Magnesium } \\
(\mathrm{Mg})(\%)\end{array}$ & $\begin{array}{l}\text { Total } \\
\text { Carbon } \\
\text { (organic } \\
\text { and } \\
\text { mineral) } \\
(\%)\end{array}$ & $\begin{array}{l}\text { Organic } \\
\text { Carbon }(\%)\end{array}$ & $\begin{array}{l}\mathrm{C} / \mathrm{N} \text { ratio } \\
\text { (total } \mathrm{C} \\
\text { and } \\
\text { total } \mathrm{N} \text { ) }\end{array}$ \\
\hline \multirow[t]{2}{*}{1} & $\mathrm{NH}$ & 4.8 & 0.50 & 0.32 & 0.24 & 0.23 & 0.51 & 1.54 & 14.62 & 10.89 & $46 / 1$ \\
\hline & DB & & & 0.36 & 0.27 & 0.26 & 0.26 & 1.73 & 16.38 & 12.20 & $46 / 1$ \\
\hline \multirow[t]{2}{*}{2} & $\mathrm{NH}$ & 6.2 & 0.47 & 0.54 & 0.44 & 0.42 & 0.66 & 2.20 & 15.97 & 14.99 & $29 / 1$ \\
\hline & DB & & & 0.64 & 0.52 & 0.50 & 0.78 & 2.61 & 18.94 & 17.78 & $46 / 1$ \\
\hline \multirow[t]{2}{*}{3} & $\mathrm{NH}$ & 6.9 & 0.50 & 0.47 & 0.51 & 0.37 & 0.50 & 1.23 & 12.57 & 10.07 & $27 / 1$ \\
\hline & DB & & & 0.57 & 0.62 & 0.45 & 0.60 & 1.48 & 15.17 & 12.15 & $27 / 1$ \\
\hline \multirow[t]{2}{*}{4} & $\mathrm{NH}$ & 7.4 & 0.51 & 0.58 & 0.62 & 0.75 & 0.59 & 1.33 & 12.92 & 10.53 & $22 / 1$ \\
\hline & DB & & & 0.71 & 0.75 & 0.91 & 0.72 & 1.62 & 15.71 & 12.8 & $22 / 1$ \\
\hline \multirow[t]{2}{*}{5} & $\mathrm{NH}$ & 7.5 & 0.55 & 0.47 & 0.38 & 0.39 & 0.47 & 0.95 & 9.251 & 7.72 & $20 / 1$ \\
\hline & DB & & & 0.57 & 0.46 & 0.47 & 0.57 & 1.15 & 1.20 & 10.56 & $20 / 1$ \\
\hline \multirow[t]{2}{*}{6} & $\mathrm{NH}$ & 8.3 & 0.52 & 0.79 & 0.97 & 1.04 & 0.66 & 1.48 & 14.13 & 12.02 & $18 / 1$ \\
\hline & DB & & & 1.00 & 1.23 & 1.32 & 0.84 & 1.88 & 17.93 & 15.25 & $18 / 1$ \\
\hline \multirow[t]{2}{*}{7} & $\mathrm{NH}$ & 6.5 & 0.55 & 0.47 & 0.41 & 0.25 & 1.13 & 1.37 & 13.55 & 10.15 & $29 / 1$ \\
\hline & DB & & & 0.57 & 0.49 & 0.30 & 1.36 & 1.65 & 16.30 & 12.21 & $29 / 1$ \\
\hline \multirow[t]{2}{*}{8} & $\mathrm{NH}$ & 6.9 & 0.58 & 0.53 & 0.58 & 0.25 & 1.42 & 0.93 & 11.47 & 10.17 & $21 / 1$ \\
\hline & DB & & & 0.63 & 0.69 & 0.30 & 1.69 & 1.11 & 13.68 & 12.13 & $21 / 1$ \\
\hline \multirow[t]{2}{*}{9} & $\mathrm{NH}$ & 7.0 & 0.76 & 0.63 & 0.65 & 0.30 & 2.03 & 0.99 & 12.08 & 10.85 & $19 / 1$ \\
\hline & DB & & & 0.71 & 0.73 & 0.34 & 2.27 & 1.11 & 13.53 & 12.16 & $19 / 1$ \\
\hline \multirow[t]{2}{*}{10} & $\mathrm{NH}$ & 7.2 & 0.77 & 0.70 & 0.69 & 0.30 & 2.22 & 0.91 & 11.26 & 8.19 & $16 / 1$ \\
\hline & DB & & & 0.78 & 0.77 & 0.33 & 2.47 & 1.01 & 12.55 & 9.13 & $16 / 1$ \\
\hline \multirow[t]{2}{*}{11} & $\mathrm{NH}$ & 7.2 & 0.77 & 0.70 & 0.74 & 0.33 & 2.53 & 1.00 & 11.94 & 10.92 & $17 / 1$ \\
\hline & DB & & & 0.78 & 0.82 & 0.37 & 2.81 & 1.11 & 13.25 & 12.12 & $17 / 1$ \\
\hline \multirow[t]{2}{*}{12} & $\mathrm{NH}$ & 8.0 & 0.56 & 0.68 & 0.82 & 0.80 & 1.00 & 0.95 & 11.89 & 10.61 & $17 / 1$ \\
\hline & DB & & & 0.78 & 0.94 & 0.92 & 1.15 & 1.09 & 13.60 & 12.16 & $17 / 1$ \\
\hline \multirow[t]{2}{*}{13} & $\mathrm{NH}$ & 7.8 & 0.65 & 0.93 & 0.95 & 0.80 & 2.08 & 1.05 & 13.48 & 13.28 & $15 / 1$ \\
\hline & $\mathrm{DB}$ & & & 1.07 & 1.09 & 0.92 & 2.39 & 1.21 & 15.49 & 15.26 & $15 / 1$ \\
\hline \multirow[t]{2}{*}{14} & $\mathrm{NH}$ & 7.7 & 0.58 & 0.93 & 0.97 & 0.80 & 2.34 & 1.25 & 15.07 & 14.68 & $16 / 1$ \\
\hline & DB & & & 1.06 & 1.11 & 0.91 & 2.67 & 1.43 & 17.21 & 16.77 & $16 / 1$ \\
\hline \multirow[t]{2}{*}{15} & $\mathrm{NH}$ & 7.7 & 0.65 & 0.96 & 1.00 & 0.41 & 2.39 & 0.71 & 12.97 & 12.31 & $14 / 1$ \\
\hline & DB & & & 1.07 & 1.11 & 0.46 & 2.66 & 0.79 & 14.45 & 13.42 & $14 / 1$ \\
\hline
\end{tabular}




\section{Results and Discussion}

Regarding the chemical analyses of soil, $\mathrm{pH}$ values were over 6.0 for all substrates, except for substrate 1 (Tab. 3). When $\mathrm{pH}$ values are over 6.0 in $\mathrm{CaCl}_{2}$, the acidity is classified as very low (Raij 1991). There are many studies that show that organic fertilization increases $\mathrm{pH}$ (Alves et al. 1999; Abreu Jr. et al. 2002; Oliveira et al. 2002); the increases observed in these studies vary according to soil, type of experiment (field or greenhouse), chemical composition of the compost, degree of maturity, and amounts applied.

In the present study the substrates that had the highest phosphorous content were 13,14 and 15 ; these substrates had significant amounts of manure and waste compost. Lima et al. (2000) in a study with Schizolobium parahyba seedlings observed that $60 \mathrm{mg}$ of $\mathrm{P}_{2} \mathrm{O}_{5}$ per $\mathrm{kg}$ of soil exhibited the best performance.

Substrate 6 exhibited the highest potassium value. Vieira et al. (2006), comparing the effects of different amounts of each nutrient on seedling growth of Schizolobium parahyba, observed that the omission of potassium showed the best averages of the variable studied for this nutrient.

The highest calcium content was found in the substrates 9, 10, 11, 13, 14 and 15. All had waste compost and/or manure in their composition (Tab. 3). Among the main effects of the application of waste compost on the chemical attributes of acid soils stand out increase in $\mathrm{pH}$, neutralization of exchangeable acidity, reduction in potential acidity, increase in the availability of phosphorus, potassium, calcium and magnesium, and increase in cationic exchange capacity (Kiehl 1985; Oliveira et. al. 2002).

In general, organic materials that were not yet decomposed are also rich in C (May 1984), which results in a high $\mathrm{C} / \mathrm{N}$ rate, favoring the use of $\mathrm{N}$ by microorganisms and causing a deficiency of this element in the seedlings. In this case, addition of a nitrogen supplement is necessary, when the $\mathrm{C} / \mathrm{N}$ rate is over 30/1. However, when values range from 15 to $20 / 1, \mathrm{~N}$ is liberated and this element becomes available for seedlings, as a result of microbial activity. For values from 20 to $30 / 1$, the immobilization rate equals the decomposition rate (May 1984). The substrates $6,9,10,11,12,13,14$ and 15 exhibited $\mathrm{C} / \mathrm{N}$ rate in the range of 15 to $20 / 1$ (Tab. 3).

A factor that affected seedling height was the low proportion of waste compost used. In substrates with low proportion of this material: treatment $7(15 \%)$ and treatment $8(30 \%)$ (Tab. 1), seedlings exhibited higher average shoot height. Fachini et al. (2004), studying orange seedlings in the greenhouse, observed that for a volume over $40 \%$, the higher the quantity of waste used in the substrate mixture, the lower was plant growth; he also observed that plants initially exhibited a yellow coloration that disappeared after some time. This observation corroborates Stringheta et al. (1996), who reported an increase in height of chrysanthemum plants as the concentration of waste compost increased up to a threshold of $45.76 \%$. After that threshold, there was a reduction in plant vertical growth, and the substrate that exhibited $100 \%$ organic waste compost had the lowest plant growth rate.

Results of the statistical analysis of shoot height $(\mathrm{H})$ are presented in Table 4, results of rootcollar diameter (D) in Table 5 and of number of leaves (NL) in Table 6. The statistical analysis of the parameters $\mathrm{H}, \mathrm{D}$ and NL showed that the substrates

Table 4-Average height of the seedlings of Schyzolobium parahyba 20, 35, 50 and 65 days after sowing.

\begin{tabular}{|c|c|c|c|c|}
\hline \multirow[t]{2}{*}{ Substrates $(\mathrm{S})$} & \multicolumn{3}{|c|}{$\begin{array}{c}\text { Plant average height }(\mathrm{cm}) \\
\text { Assessed Periods (d.a.s) }\end{array}$} & \multirow[b]{2}{*}{65} \\
\hline & 20 & 35 & 50 & \\
\hline 1 & $11.73 \mathrm{a}$ & $14.04 \mathrm{a}$ & $15.06 \mathrm{a}$ & $17.59 \mathrm{~b}$ \\
\hline 2 & $10.69 \mathrm{a}$ & $14.38 \mathrm{a}$ & $15.38 \mathrm{a}$ & $17.59 \mathrm{~b}$ \\
\hline 3 & $12.82 \mathrm{a}$ & $15.08 \mathrm{a}$ & $16.44 \mathrm{a}$ & $17.24 \mathrm{~b}$ \\
\hline 4 & $11.99 \mathrm{a}$ & $13.65 \mathrm{a}$ & $15.75 \mathrm{a}$ & $16.16 \mathrm{~b}$ \\
\hline 5 & $11.91 \mathrm{a}$ & $13.11 \mathrm{a}$ & $15.05 \mathrm{a}$ & $15.72 b$ \\
\hline 6 & $10.31 \mathrm{a}$ & $12.42 \mathrm{a}$ & $13.34 \mathrm{a}$ & $15.23 \mathrm{~b}$ \\
\hline 7 & $12.34 \mathrm{a}$ & $16.24 \mathrm{a}$ & $18.39 \mathrm{a}$ & $21.90 \mathrm{a}$ \\
\hline 8 & $11.03 \mathrm{a}$ & $15.77 \mathrm{a}$ & $18.24 \mathrm{a}$ & $19.46 \mathrm{a}$ \\
\hline 9 & $9.71 \mathrm{a}$ & $13.16 \mathrm{a}$ & $15.86 \mathrm{a}$ & $16.94 \mathrm{~b}$ \\
\hline 10 & $10.87 \mathrm{a}$ & $13.17 \mathrm{a}$ & $14.74 \mathrm{a}$ & $15.27 \mathrm{~b}$ \\
\hline 11 & $11.12 \mathrm{a}$ & $12.61 \mathrm{a}$ & $15.60 \mathrm{a}$ & $16.51 \mathrm{~b}$ \\
\hline 12 & $12.17 \mathrm{a}$ & $14.39 \mathrm{a}$ & $14.89 \mathrm{a}$ & $15.50 \mathrm{~b}$ \\
\hline 13 & $12.24 \mathrm{a}$ & $13.85 \mathrm{a}$ & $15.03 \mathrm{a}$ & $15.98 \mathrm{~b}$ \\
\hline 14 & $11.22 \mathrm{a}$ & $13.81 \mathrm{a}$ & $16.28 \mathrm{a}$ & $17.20 \mathrm{~b}$ \\
\hline 15 & $9.19 \mathrm{a}$ & $14.39 \mathrm{a}$ & $16.41 \mathrm{a}$ & $17.95 \mathrm{~b}$ \\
\hline F Test & $1.39 \mathrm{NS}$ & $1.32 \mathrm{NS}$ & $2.46 \mathrm{NS}$ & $3.11 * *$ \\
\hline $\begin{array}{l}\text { Irrigation } \\
\text { Levels (I) }\end{array}$ & \multicolumn{4}{|c|}{ Assessed Periods (d.a.s) } \\
\hline 1 & $11.59 \mathrm{a}$ & $13.53 \mathrm{a}$ & $16.70 \mathrm{a}$ & $16.03 \mathrm{~b}$ \\
\hline 2 & $10.99 \mathrm{a}$ & $14.48 \mathrm{a}$ & $14.83 \mathrm{~b}$ & $18.19 \mathrm{a}$ \\
\hline F Test & $1.76^{\mathrm{NS}}$ & $3.76^{\mathrm{NS}}$ & $19.17 * *$ & $17.23 * *$ \\
\hline $\mathrm{S} \times \mathrm{I}$ & $1.28 \mathrm{NS}$ & $1.23 \mathrm{NS}$ & $1.66^{\mathrm{NS}}$ & $1.24 \mathrm{NS}$ \\
\hline $\mathrm{CV}(\%)$ & 15.41 & 13.50 & 10.49 & 11.80 \\
\hline
\end{tabular}

Averages followed by the same letter in the column did not differ at $5 \%$ significance level in Scott Knott's test $(n=4)$.

Ns stands for non-significant at $5 \%$ level, * significant at $1 \%$ level, ** significant at $5 \%$ level, $\mathrm{CV}$ is the coefficient of variation, and $\mathrm{S}$ ' $\mathrm{I}$ is the interaction between substrate and irrigation. d.a.s.: Days after sowing. 
Table 5 - Root-collar diameter of Schyzolobium parahyba seedlings 20,35, 50 and 65 days after sowing.

\begin{tabular}{|c|c|c|c|c|}
\hline \multirow[t]{2}{*}{ Substrates(S) } & \multicolumn{4}{|c|}{$\begin{array}{l}\text { Root-collar Diameter (mm) } \\
\text { Assessed Periods (d.a.s) }\end{array}$} \\
\hline & 20 & 35 & 50 & 65 \\
\hline 1 & $3.47 \mathrm{a}$ & $3.95 \mathrm{a}$ & $4.03 \mathrm{a}$ & $4.06 \mathrm{a}$ \\
\hline 2 & $3.72 \mathrm{a}$ & $3.84 \mathrm{a}$ & $3.90 \mathrm{a}$ & $4.02 \mathrm{a}$ \\
\hline 3 & $3.58 \mathrm{a}$ & $3.74 \mathrm{a}$ & $3.83 \mathrm{a}$ & $3.84 \mathrm{a}$ \\
\hline 4 & $3.60 \mathrm{a}$ & $3.66 \mathrm{a}$ & $3.69 \mathrm{a}$ & $3.77 \mathrm{a}$ \\
\hline 5 & $3.42 \mathrm{a}$ & $3.63 \mathrm{a}$ & $3.91 \mathrm{a}$ & $4.03 \mathrm{a}$ \\
\hline 6 & $3.45 \mathrm{a}$ & $3.60 \mathrm{a}$ & $3.63 \mathrm{a}$ & $3.76 \mathrm{a}$ \\
\hline 7 & $3.63 \mathrm{a}$ & $3.72 \mathrm{a}$ & $3.87 \mathrm{a}$ & $3.92 \mathrm{a}$ \\
\hline 8 & $3.90 \mathrm{a}$ & $4.00 \mathrm{a}$ & $4.05 \mathrm{a}$ & $4.14 \mathrm{a}$ \\
\hline 9 & $3.69 \mathrm{a}$ & $3.76 \mathrm{a}$ & $3.91 \mathrm{a}$ & $3.97 \mathrm{a}$ \\
\hline 10 & $3.42 \mathrm{a}$ & $3.62 \mathrm{a}$ & $3.99 \mathrm{a}$ & $4.00 \mathrm{a}$ \\
\hline 11 & $3.70 \mathrm{a}$ & $3.80 \mathrm{a}$ & $4.04 \mathrm{a}$ & $4.10 \mathrm{a}$ \\
\hline 12 & $3.89 \mathrm{a}$ & $4.02 \mathrm{a}$ & $4.06 \mathrm{a}$ & $4.09 \mathrm{a}$ \\
\hline 13 & $3.79 \mathrm{a}$ & $3.84 \mathrm{a}$ & $3.94 \mathrm{a}$ & $4.11 \mathrm{a}$ \\
\hline 14 & $3.70 \mathrm{a}$ & $3.85 \mathrm{a}$ & $4.00 \mathrm{a}$ & $4.03 \mathrm{a}$ \\
\hline 15 & $3.74 \mathrm{a}$ & $3.97 \mathrm{a}$ & $4.09 \mathrm{a}$ & $4.17 \mathrm{a}$ \\
\hline F Test & $0.93^{\mathrm{NS}}$ & $1.00^{\mathrm{NS}}$ & $1.01^{\mathrm{NS}}$ & $0.92 \mathrm{NS}$ \\
\hline $\begin{array}{l}\text { Irrigation } \\
\text { Levels(I) }\end{array}$ & \multicolumn{4}{|c|}{ Assessed Periods (d.a.s) } \\
\hline 1 & $3.75 \mathrm{a}$ & $3.90 \mathrm{a}$ & $4.00 \mathrm{a}$ & $4.05 \mathrm{a}$ \\
\hline 2 & $3.65 \mathrm{~b}$ & $3.70 \mathrm{~b}$ & $3.86 \mathrm{a}$ & $3.95 \mathrm{a}$ \\
\hline F Test & $4.90 *$ & $7.35 *$ & $4.08 \mathrm{NS}$ & $1.98 \mathrm{NS}$ \\
\hline $\mathrm{S} \times \mathrm{I}$ & $1.03 \mathrm{NS}$ & 0.98 NS & $1.26 \mathrm{NS}$ & $0.89 \mathrm{NS}$ \\
\hline $\mathrm{CV}$ & 9.24 & 7.43 & 6.81 & 6.57 \\
\hline
\end{tabular}

Averages followed by the same letter in the column did not differ at $5 \%$ significance level in Scott Knott's test $(n=4)$.

${ }^{\mathrm{Ns}}$ stands for non-significant at $5 \%$ level, ${ }^{*}$ significant at $1 \%$ level, ${ }^{* *}$ significant at $5 \%$ level, $\mathrm{CV}$ is the coefficient of variation, and $\mathrm{S} \times \mathrm{I}$ is the interaction between substrate and irrigation.

d.a.s.: Days after sowing.

had significant effects on the growth of the Brazilian firetree for the parameter shoot height 65 d.a.s. Substrates 7 and 8 (Plantmax ${ }^{\circledR}$, waste compost, vermiculite and soil) provided the highest values for this parameter. This observation contradicts the results obtained by Sabonaro et al. (2009), who studied seedling production of Tabebuia heptaphylla Vell. with different combinations of materials: Plantmax ${ }^{\circledR}$, dry cattle manure, vermiculite and soil. These authors concluded that urban waste compost hinders seedling growth, producing lower values of shoot height and root-collar diameter, due to $\mathrm{pH}$, density and $\mathrm{C} / \mathrm{N}$ ratio, independently of the dose applied.

The Brazilian firetree is a pioneer species and one of the fastest-growing native species. Pioneer species have their growth reduced in poor soils,
Table 6 - Number of leaves of Schyzolobium parahyba seedlings 20, 35, 50 and 65 days after sowing.

\begin{tabular}{|c|c|c|c|c|}
\hline \multirow{2}{*}{ Substrates (S) } & \multicolumn{4}{|c|}{$\begin{array}{l}\text { Number of leaves (NL) } \\
\text { Assessed Periods (d.a.s) }\end{array}$} \\
\hline & 20 & 35 & 50 & 65 \\
\hline 1 & $3.20 \mathrm{a}$ & $5.12 \mathrm{a}$ & $7.80 \mathrm{a}$ & $9.35 \mathrm{a}$ \\
\hline 2 & $3.17 \mathrm{a}$ & $5.42 \mathrm{a}$ & $8.20 \mathrm{a}$ & $9.42 \mathrm{a}$ \\
\hline 3 & $3.47 \mathrm{a}$ & $4.60 \mathrm{a}$ & $7.15 \mathrm{a}$ & $8.52 \mathrm{a}$ \\
\hline 4 & $3.62 \mathrm{a}$ & $4.72 \mathrm{a}$ & $7.85 \mathrm{a}$ & $9.10 \mathrm{a}$ \\
\hline 5 & $3.10 \mathrm{a}$ & $4.12 \mathrm{a}$ & $6.50 \mathrm{a}$ & $7.57 \mathrm{a}$ \\
\hline 6 & $3.42 \mathrm{a}$ & $4.20 \mathrm{a}$ & $5.92 \mathrm{a}$ & $7.12 \mathrm{a}$ \\
\hline 7 & $3.32 \mathrm{a}$ & $5.32 \mathrm{a}$ & $8.20 \mathrm{a}$ & $10.75 \mathrm{a}$ \\
\hline 8 & $3.15 \mathrm{a}$ & $5.85 \mathrm{a}$ & $9.17 \mathrm{a}$ & $10.50 \mathrm{a}$ \\
\hline 9 & $3.05 \mathrm{a}$ & $5.00 \mathrm{a}$ & $7.90 \mathrm{a}$ & $10.50 \mathrm{a}$ \\
\hline 10 & $3.10 \mathrm{a}$ & $3.77 \mathrm{a}$ & $7.45 \mathrm{a}$ & $9.0 \mathrm{a}$ \\
\hline 11 & $3.27 \mathrm{a}$ & $4.67 \mathrm{a}$ & $8.30 \mathrm{a}$ & $8.77 \mathrm{a}$ \\
\hline 12 & $3.20 \mathrm{a}$ & $4.27 \mathrm{a}$ & $6.67 \mathrm{a}$ & $8.0 \mathrm{a}$ \\
\hline 13 & $3.82 \mathrm{a}$ & $4.40 \mathrm{a}$ & $7.60 \mathrm{a}$ & $8.45 \mathrm{a}$ \\
\hline 14 & $3.27 \mathrm{a}$ & $4.92 \mathrm{a}$ & $8.25 \mathrm{a}$ & $9.42 \mathrm{a}$ \\
\hline 15 & $3.07 \mathrm{a}$ & $5.67 \mathrm{a}$ & $10.20 \mathrm{a}$ & $11.92 \mathrm{a}$ \\
\hline $\mathrm{F}$ Test & 3.89 NS & $1.45^{\mathrm{NS}}$ & 2.03 NS & 1.74 NS \\
\hline $\begin{array}{l}\text { Irrigation } \\
\text { Levels (I) } \\
\end{array}$ & \multicolumn{4}{|c|}{ Assessed Periods (d.a.s) } \\
\hline 1 & $3.43 \mathrm{a}$ & $5.90 \mathrm{a}$ & $6.74 \mathrm{~b}$ & $8.03 \mathrm{~b}$ \\
\hline 2 & $3.14 \mathrm{a}$ & $3.71 \mathrm{~b}$ & $8.87 \mathrm{a}$ & $10.42 \mathrm{a}$ \\
\hline F Test & 0.63 NS & $72.8 * *$ & $31.81 * *$ & $22.68 * *$ \\
\hline $\mathrm{S} \times \mathrm{I}$ & 0.49 NS & 1.17 NS & $0.52 \mathrm{NS}$ & $0.73 \mathrm{NS}$ \\
\hline $\mathrm{CV}$ & 16.93 & 20.77 & 18.90 & 21.06 \\
\hline
\end{tabular}

Averages followed by the same letter in the column did not differ at $5 \%$ significance level in Scott-Knott's test $(n=4)$.

${ }^{\mathrm{NS}}$ stands for non-significant at $5 \%$ level, * significant at $1 \%$ level, ** significant at $5 \%$ level, $\mathrm{CV}$ is the coefficient of variation, and $\mathrm{S} \times \mathrm{I}$ is the interaction between substrate and irrigation.

d.a.s.: Days after sowing.

and respond well to fertilization; whereas in plants of later successional groups, the stimulus provided by fertilization is less pronounced and sometimes absent. This trend is attributed, in part, to the slower growth characteristic of climax species (Rezende et al. 1995).

There were significant differences between irrigation levels in shoot height in the assessments carried out 50 and 65 d.a.s. (Tab. 4), in root-collar diameter in the assessments carried out 20 and 35 d.a.s. (Tab. 5), and in the number of leaves in the assessments carried out 35, 50 and 65 d.a.s. (Tab. 6). Therefore, it is possible to infer that, for this species, water needs vary with seedling growth stage. This observation corroborates Sabonaro et al. (2009) who concluded that, during seedling growth of Tabebuia heptaphylla, water need is variable and related to seedling growth stage. 
Table 7 - Summary of the analysis of variance for Schyzolobium parahyba seedlings: root and shoot dry weight 65 days after sowing.

\begin{tabular}{|c|c|c|}
\hline Substrates(S) & $\begin{array}{l}\text { Root } \\
\text { Dry Weight } \\
(\mathrm{g} \text { plant }-1)\end{array}$ & $\begin{array}{l}\text { Shoot } \\
\text { Dry Weight } \\
(\mathrm{g} \text { plant }-1)\end{array}$ \\
\hline 1 & $0.41 \mathrm{~b}$ & $0.61 \mathrm{a}$ \\
\hline 2 & $0.29 \mathrm{~b}$ & $0.49 \mathrm{~b}$ \\
\hline 3 & $0.45 \mathrm{~b}$ & $0.42 \mathrm{~b}$ \\
\hline 4 & $0.32 \mathrm{~b}$ & $0.46 \mathrm{~b}$ \\
\hline 5 & $0.25 \mathrm{~b}$ & $0.40 \mathrm{~b}$ \\
\hline 6 & $0.36 \mathrm{~b}$ & $0.51 \mathrm{~b}$ \\
\hline 7 & $0.45 \mathrm{~b}$ & $0.80 \mathrm{a}$ \\
\hline 8 & $0.60 \mathrm{a}$ & $0.82 \mathrm{a}$ \\
\hline 9 & $0.55 \mathrm{a}$ & $0.76 \mathrm{a}$ \\
\hline 10 & $0.34 \mathrm{~b}$ & $0.45 \mathrm{~b}$ \\
\hline 11 & $0.30 \mathrm{~b}$ & $0.42 \mathrm{~b}$ \\
\hline 12 & $0.62 \mathrm{a}$ & $0.37 \mathrm{~b}$ \\
\hline 13 & $0.48 \mathrm{a}$ & $0.71 \mathrm{a}$ \\
\hline 14 & $0.64 \mathrm{a}$ & $0.71 \mathrm{a}$ \\
\hline 15 & $0.60 \mathrm{a}$ & $0.82 \mathrm{a}$ \\
\hline F Test & $2.20 *$ & $3.52 * *$ \\
\hline \multicolumn{3}{|l|}{$\begin{array}{l}\text { Irrigation } \\
\text { Level (I) }\end{array}$} \\
\hline I & $0.38 \mathrm{~b}$ & $0.50 \mathrm{~b}$ \\
\hline II & $0.51 \mathrm{a}$ & $0.66 \mathrm{a}$ \\
\hline F Test & $7.64 * *$ & $11.95 * *$ \\
\hline $\mathrm{S} \times \mathrm{I}$ & $0.92 \mathrm{NS}$ & $2.08 *$ \\
\hline $\mathrm{CV}(\%)$ & 40.76 & 30.73 \\
\hline
\end{tabular}

Averages followed by the same letter in the column did not differ at $5 \%$ significance level in Scott Knott's test $(n=4)$.

${ }^{\mathrm{Ns}}$ stands for non-significant at $5 \%$ level, ${ }^{*}$ significant at $1 \%$ level, ${ }^{* *}$ significant at $5 \%$ level, $\mathrm{CV}$ is the coefficient of variation, and $\mathrm{S} \times \mathrm{I}$ is the interaction between substrate and irrigation.

There were significant differences for shoot dry weight (Tab. 7). For root dry weight, the plants in substrates $8,9,12,13,14$ and 15 exhibited the highest averages. For shoot dry weight, the plants in substrates $1,7,8,9,13,14$ and 15 exhibited the highest averages

There were significant differences among irrigation levels for dry weight (Tab. 7). This observation corroborates Fachini et al. (2004), who assessed dry weight in a culture of citrus seedlings in substrates in protected environment, and observed that roots with higher weight were those from plants with irrigation levels 100 and $150 \%$ ET.

The ratio between shoot height and rootcollar diameter (H/D) showed favorable values for the establishment of plants after sowing (Tab. 8). Carneiro (1976), studying Pinus taeda, reported that values varying from 5.4 to 8.1 are ideal for the ratio H/D. According to Carneiro
Table 8 - Summary of the analysis of variance: ratio between shoot height/root-collar diameter (H/D), total dry weight, ratio between shoot height/shoot dry weight $(\mathrm{H} /$ SDW), shoot dry weight/root dry weight (SDW/RDW), and Dickson's quality index (DQI) 65 days after sowing.

\begin{tabular}{|c|c|c|c|c|c|}
\hline $\begin{array}{l}\text { Substrates } \\
\text { (S) }\end{array}$ & H/D & $\begin{array}{l}\text { RDM+ } \\
\text { SDM }\end{array}$ & H/SDM & $\begin{array}{l}\text { SDM/ } \\
\text { RDM }\end{array}$ & DQI \\
\hline 1 & $4.42 \mathrm{~b}$ & $1.02 \mathrm{~b}$ & $32.4 \mathrm{~b}$ & $1.60 \mathrm{a}$ & $0.17 \mathrm{a}$ \\
\hline 2 & $4.52 \mathrm{~b}$ & $0.81 \mathrm{~b}$ & $39.85 \mathrm{a}$ & $1.42 \mathrm{a}$ & $0.14 \mathrm{a}$ \\
\hline 3 & $4.27 \mathrm{~b}$ & $0.74 \mathrm{~b}$ & $44.52 \mathrm{a}$ & $1.17 \mathrm{a}$ & $0.13 \mathrm{a}$ \\
\hline 4 & $4.33 \mathrm{~b}$ & $0.84 \mathrm{~b}$ & $32.82 \mathrm{~b}$ & $1.87 \mathrm{a}$ & $0.14 \mathrm{a}$ \\
\hline 5 & $3.91 \mathrm{~b}$ & $0.75 \mathrm{~b}$ & $50.12 \mathrm{a}$ & $1.12 \mathrm{a}$ & $0.15 \mathrm{a}$ \\
\hline 6 & $4.36 \mathrm{~b}$ & $0.87 \mathrm{~b}$ & $32.02 \mathrm{~b}$ & $1.72 \mathrm{a}$ & $0.19 \mathrm{a}$ \\
\hline 7 & $5.51 \mathrm{a}$ & $1.33 \mathrm{a}$ & $28.02 \mathrm{c}$ & $1.67 \mathrm{a}$ & $0.19 \mathrm{a}$ \\
\hline 8 & $4.50 \mathrm{~b}$ & $1.36 \mathrm{a}$ & $23.75 \mathrm{c}$ & $1.35 \mathrm{a}$ & $0.23 \mathrm{a}$ \\
\hline 9 & $3.98 \mathrm{~b}$ & $1.13 \mathrm{a}$ & $25.67 \mathrm{c}$ & $1.62 \mathrm{a}$ & $0.25 \mathrm{a}$ \\
\hline 10 & $4.26 \mathrm{~b}$ & $1.37 \mathrm{a}$ & $35.50 \mathrm{~b}$ & $1.30 \mathrm{a}$ & $0.25 \mathrm{a}$ \\
\hline 11 & $4.00 \mathrm{~b}$ & $0.74 \mathrm{~b}$ & $47.02 \mathrm{a}$ & $1.17 \mathrm{a}$ & $0.14 \mathrm{a}$ \\
\hline 12 & $3.62 \mathrm{~b}$ & $1.00 \mathrm{~b}$ & $41.07 \mathrm{a}$ & $0.77 \mathrm{a}$ & $0.22 \mathrm{a}$ \\
\hline 13 & $3.95 \mathrm{~b}$ & $1.29 \mathrm{a}$ & $24.72 \mathrm{c}$ & $2.45 \mathrm{a}$ & $0.46 \mathrm{a}$ \\
\hline 14 & $4.36 \mathrm{~b}$ & $1.55 \mathrm{a}$ & $22.82 \mathrm{c}$ & $1.15 \mathrm{a}$ & $0.28 \mathrm{a}$ \\
\hline 15 & $4.27 \mathrm{~b}$ & $1.53 \mathrm{a}$ & $26.17 \mathrm{c}$ & $0.83 \mathrm{a}$ & $0.30 \mathrm{a}$ \\
\hline F Test & $3.48 * *$ & $3.18 * *$ & $5.32 * *$ & $0.77^{\mathrm{NS}}$ & 1.56 NS \\
\hline $\begin{array}{l}\text { Irrigation } \\
\text { Levels (I) }\end{array}$ & H/D & $\begin{array}{l}\text { RDM+ } \\
\text { SDM }\end{array}$ & H/SDM & $\begin{array}{l}\text { SDM/ } \\
\text { RDM }\end{array}$ & DQI \\
\hline 1 & $3.96 \mathrm{~b}$ & $0.95 \mathrm{~b}$ & $38.75 \mathrm{a}$ & $1.43 \mathrm{a}$ & $0.21 \mathrm{a}$ \\
\hline 2 & $4.61 \mathrm{a}$ & $1.21 \mathrm{a}$ & $28.99 \mathrm{~b}$ & $1.43 \mathrm{a}$ & $0.20 \mathrm{a}$ \\
\hline F Test & $25.92 * *$ & $8.32 * *$ & $26.37 * *$ & $0.00^{\mathrm{NS}}$ & $0.00^{\mathrm{NS}}$ \\
\hline $\mathrm{S} \times \mathrm{I}$ & $1.28 \mathrm{NS}$ & $1.65 \mathrm{NS}$ & $4.28 * *$ & $1.56 \mathrm{NS}$ & 0.99 NS \\
\hline $\mathrm{CV}$ & 11.45 & 31.36 & 21.74 & 63.77 & 68.67 \\
\hline
\end{tabular}

(1995), the lower this value is, the greater will be the capacity for those seedlings to survive and establish themselves.

The ratio between shoot dry weight and root dry weight (SDW/RDW) showed no significant difference among all substrates studied. Brissete (1984) proposed that 2.0 would be the best ratio between these attributes. In the present study, there was high variation of these values ( 0.77 to 2.45 ), but only for substrate 13 the value was over $2.0 \mathrm{~g} \mathrm{plant}^{-1}$ (Tab. 8).

Dickson's Quality Index (DQI) did not differ among treatments. According to Gomes et al. (2002), the higher the quality of this index, the better the quality of the seedlings. Hunt (1990) recommended a minimum value of 0.20 ; the Brazilian firetree in the present study reached this value in substrates 8,9 , $10,12,13,14$ and 15 (all with waste compost in their composition), showing that their quality is sufficient to allow planting in the field (Table 8). 
Hence, it is possible to infer that for Schizolobium parahyba the waste compost proportions used in the substrates were not harmful, and resulted in significant differences for the parameters shoot height, H/D and DQI. It is, therefore, possible to use waste compost in the substrate for cultivating Schizolobium parahyba.

\section{Acknowledgements}

Fundação de Amparo à Pesquisa do Estado de São Paulo (FAPESP) funded this research.

\section{References}

Abreu Jr., C.H.; Muraoka, T. \& Oliveira, F.C. 2002. Carbono, nitrogênio, fósforo e enxofre em solos tratados com composto de lixo urbano. Revista Brasileira de Ciência do Solo 26: 769-780.

Abreu Jr., C.H.; Muraoka, T.; Lavorante, A.F. \& Alvarez, V.F.C. 2000. Condutividade elétrica, reação do solo e acidez potencial em solos adubados com composto lixo. Revista Brasileira de Ciência do Solo 24: 645-657.

Alves, W.L.; Melo, W.J. \& Ferreira, M.E. 1999. Efeito do composto de lixo urbano em um solo arenoso e em plantas de sorgo. Revista Brasileira de Ciência do Solo 23: 729-736.

Brissette, J.C. 1984. Summary of discussions about seedling quality. In: Lantz, C.W. (ed.). Proceedings, Southern Nursery Conference Alexandria, LA. United States Department of Agriculture, Forest Service, Atlanta. Pp. 127-128.

Broner, I. \& Law, R.A.P. 1991. Evaluation of modified atmometer for estimating reference ET. Irrigation Scientia 12: 21-26.

Burnett, A.N. 1979. New methods for measuring root growth capacity: their value in assessing lodgepole pine stock quality. Canadian Journal of Forest Research 9: 63-67.

Carneiro, J.G.A. 1995. Variações na metodologia de produção de mudas florestais afetam os parâmetros morfológicos que indicam sua qualidade de mudas florestais. UFPR/FUNEP, Curitiba. 451p.

Carneiro, J.G.A. 1976. Determinação do padrão de qualidade de mudas de Pinus taeda L. para plantio definitivo. Dissertação de Mestrado. Universidade Federal do Paraná, Curitiba. 70p.

Dickson, A.; Leaf, A. \& Hosner, J.F. 1960. Quality appraisal of white spruce and white pine seedling stock in nurseries. Forestry Chronicle 36: 10-13.

Fachini, E.; Galbiatti, J.A. \& Pavani, L.C. 2004. Níveis de irrigação e de composto de lixo orgânico na formação de mudas cítricas em casa de vegetação. Engenharia Agrícola 24: 578-588.
Gonçalves, J.L.M. \& Poggiani, F. 1996. Substratos para produção de mudas florestais. In: Congresso Latino Americano de Ciência do Solo, 13. Resumos. CDRom. Sociedade Latino Americana de Ciência do Solo, Piracicaba.

Gomes, J.M. 2001. Parâmetros morfológicos na avaliação da qualidade de mudas de Eucalyptus grandis, produzidas em diferentes tamanhos de tubete e de dosagens de N-P-K. Tese de Doutorado. Universidade Federal de Viçosa, Viçosa. 166p.

Gonçalves, J.L.M.; Van Raij, B. \& Gonçalves, J.C. 1997. Florestais. In: van Raij, B.; Cantarella, H.; Quaggio, J.A. \& Furlani, A.M.C. (eds.). Recomendações de adubação e calagem para o estado de São Paulo. 2ed. Boletim Técnico, 100. Instituto Agronômico/Fundação IAC, Campinas. Pp. 245-259.

Gomes, J.M.; Couto, L.; Leite, H.G.; Xavier, A. \& Garcia, S.L.R. 2002. Parâmetros morfológicos na avaliação da qualidade de mudas de Eucalyptus grandis. Revista Árvore 26: 655-664.

Hunt, G.A. 1990. Effect of stryroblock design and copper treatament on morphology of conifer seedlings. In: Rose, R.; Campbell, S.J. \& Landis, T. D. (eds.). Target Seedling Symposium: proceedings, combined meeting of the Western Forest Nursery Associations. United States Departament of Agriculture, Foresty Service, Roseburg. Available in $<$ http://www.rngr.net/publications/proceedings/1990/ WFCNA>. Accessed on 06 Jun 2011.

Kiehl, E.J. Fertilizantes orgânicos. 1995. Agronômica Ceres, São Paulo. 492p.

Ledo, A.A.M. 1977.Estudo da causa de dormência em sementes de guapuruvu (Schzolobium parahyba (Vell) Blake) e orelha de negro (Enterolobium contortisiliquum (Vell) Morong) e métodos para sua quebra. Dissertação de Mestrado. Universidade Federal de Viçosa, Viçosa. 57p.

Lima, J.P.C.; Mello Filho, J.A.; Freire, L.R. \& Vieira, F. 2000. Absorção de nitrogênio para Schizolobium parahyba (Vell.) Blake, em fase de viveiro em três ambientes. Floresta e Ambiente 7: 11-18.

Lorenzi, H. 1992. Árvores brasileiras: manual de identificação e cultivo de plantas arbóreas nativas do Brasil. Plantarum, Nova Odessa. 352p.

May, J.T. 1984. Basic concepts of soils management. In: SOUTHERN pine nursery handbook. (S.I.). Chap. 1. United States Departament of Agriculture, Foresty Service, Southern Region. Pp. 1-25.

Nóbrega, R.S.A.; Paula, A.S. \& Custódio, R. 2008. Parâmetros morfológicos de mudas de Sesbania virgata (Caz.) Pers e de Anadenanthera peregrina (L.) cultivadas em substrato fertilizado com composto de lixo urbano. Revista Árvore 32: 597-607.

Oliveira, F.C.; Mattiozo, M.E.; Marciano, C.R. \& Abreu Jr., C.H., 2002. Alterações em atributos químicos de um Latossolo pela aplicação de composto de lixo urbano. Pesquisa Agropecuária Brasileira 37:529-538. 
Rezende, L.P.; Amaral, A.M.; Carvalho, S.A. \& Souza, M. 1995.Volume de substrato e superfosfato simples na formação do limoeiro 'cravo' em vasos. Efeito no crescimento vegetativo. Laranja 16: 154-64.

Sabonaro, D.Z.; Galbiatti, J.A.; Paula, R.C. \& Gonzales, J.L.S. 2009. Producción de plantas de Tabebuia heptaphylla en diferentes sustratos y niveles de irrigación, en condiciones de invernadero. Bosque 30: 27-35.

Stringheta, A.C.O.; Fontes, L.E.F.; Lopes, L.C. \& Cardoso, A.A. 1996. Crescimento de crisântemo em substrato contendo composto de lixo urbano e casca de arroz carbonizada. Pesquisa Agropecuária Brasileira 31: 795-802.

Tomé Júnior, J.B. 1997. Manual para interpretação de análise do solo. Agropecuária, Guaíba. 247p.

Wendling, I.; Gatto, A. 2002. Substratos, adubação e irrigação na produção de mudas. Aprenda Fácil Editora, Viçosa. 166p.
Wong, M.T.F.; Nortcliff, S. \& Swift, R.S. 1998. Method for determining the acid ameliorating capacity of plant residue compost, urban waste compost, farmyard manure, and peat applied to tropical soils. Communications in Soil Science and Plant Analysis, 29: 2927-2937.

Vieira, H.V.; Locatelli, M.; França, J. M. \& Carvalho, J.O.M. 2006. Crescimento de mudas de Schizolobium parahyba var. amazonicum (Huber ex Ducke) Barneby sob diferentes níveis de nitrogênio, fósforo e potássio. Série Boletim de Pesquisa e Desenvolvimento. Embrapa Rondônia), 31. Available in <http://ainfo. cnptia.embrapa.br/digital/bitstream/item/24660/ 1/bpd31-schizolobium-parahyba.pdf $>$. Accessed on 06 Jun 2011.

Xin, T.H.; Traina, S.J. \& Logan, T.J. 1992. Chemical properties of municipal solid waste compost. Journal of Environmental Quality 21: 318-329. 